\title{
Export Promotion Aims and Reality: A Comparison of the Iberian, Baltic and Central European Region ${ }^{1}$
}

\author{
Andrea Éltető \\ Institute of World Economics, CERS, \\ Hungarian Academy of Sciences \\ Budaörsi u. 45, \\ Budapest 1112, Hungary \\ E-mail: elteto.andrea@krtk.mta.hu \\ Katalin Antalóczy \\ Faculty of International \\ Management and Business, \\ Budapest Business School \\ Diósy L. u. 22-24, \\ Budapest $\mathrm{H}-1165$, Hungary \\ E-mail: antaloczy.katalin@uni-bge.hu
}

Abstract: As a consequence of the international crisis in 2008-2009, the role of exports in economic growth came into focus in most countries. Exports of EU Member States gained momentum from 2010 onward but with certain changes in their structure and direction. In several countries, the turn towards non-EU areas, such as China or Latin America was part of the state export strategy. On the one hand, our article describes these foreign trade strategies and their institutional framework of the Iberian, Baltic and Central European governments, detecting possible similarities. On the other hand, we analyse recent export data. This way we can get a picture on the structure and direction of exports of periphery economies and this can be compared to the aims of the given states.

1 The article was prepared on the basis of a research paper by Antalóczy and Éltetö (2016) supported by the National Research, Development and Innovation Office, project no. K115578, titled 'Factors influencing export performance-a comparison of three European regions'. 
Our hypothesis is that there is a gap between the reality and the intentions of the governments. The size of this gap varies and is influenced by certain factors such as the different involvement of multinational companies in foreign trade or the different economic structure of these countries. In our paper we list which countries adopted a government strategy and with what aim. We provide a short literature review on state trade promotion policies and discuss these policies and their institutions in the Baltic, Visegrád and Iberian countries.

Keywords: comparative studies of particular economies, empirical studies of trade, international trade organisations, trade policy

\section{Export promotion policy}

The international crisis in 2009 caused a shrinkage of domestic demand and a general credit crunch. As a consequence, export became an important factor of possible growth in the majority of EU countries. In this context, state export promoting policy became relevant. In most cases the ratio of export per GDP has increased after the crisis in the EU countries. ${ }^{2}$

There exists considerable literature on trade promoting institutions, strategies and their effectiveness in general. Several empirical articles try to correlate export growth and promotion measures (e.g., Rose, 2007; Nitsch, 2005) and others show the results of questionnaire surveys (e.g., Kotabe \& Czinkota, 1992; Singer \& Czinkota, 1994). In general, the state can stimulate export via 'soft' interventions and by direct financing (credits, subsidies).

Diplomacy and export promotion programs belong to the 'soft' group (Van Biesebroeck et al., 2015). Exports of a given country are facilitated by its consulates and embassies abroad. Rose (2007) applying a gravity model of 22 countries (including Spain and Poland) and 200 destinations shows that the presence of foreign missions is indeed positively correlated with exports. The extent of correlation varies by exporter, and the first foreign mission has a larger effect on exports than successive missions.

2 Between 2007 and 2015 the share of exports of goods and services in GDP of the Visegrád group increased from an average $67 \%$ to $80 \%$, in the case of the Baltic group from $51 \%$ to $72 \%$ and for the Iberian countries from $28 \%$ to $37 \%$ (Eurostat data). 
Business delegations and heads of state visits can also promote economic relations (export and investment). Evidence of their export-raising effects is mixed for certain large countries in the post-state visit periods, when higher export was detected (Nitsch, 2005); however, the findings of Head and Ries (2010) do not confirm such effect in the case of Canada. Similarly, the metaanalysis of Moons and van Bergeijk (2013) conclude that the literature on the impact of economic diplomacy on trade is rather ambiguous.

Regarding state export promotion programs and agencies, their primary role is to provide information to firms and help them reduce transaction costs. The efficiency of export promotion agencies is generally debated. In some cases positive effects can be found and in other cases effects are non-significant (see literature review in Durmuşoğlu et al., 2012).

An important and relevant question is whether the state promotion programs could mitigate the negative impacts of the 2008 crisis, helping firms to recover. By the example of Peru and Belgium, Van Biesebroeck and others (2015) provided evidence that firms who received export support during the crisis performed better. They were more likely to remain active on export markets and exported higher volumes relative to control firms. The authors found that the effects were stronger for exports outside the EU for Belgium and the effects were particularly strong at the extensive margin (entering of new exporting firms). As shown in the article, the expenses on export promotion have been very small compared to the export value of the countries.

Export is a complex task, involving several risks. Regarding direct export financing, payment should be secure and timely, possibly not costly, adequate financing method should be selected. Commercial, bank and country risks can be various (non-payment, damaged goods, political, economic and exchange rate measures in the target country, etc., Malaket, 2014). State help in any of these factors can be very useful, especially for SMEs. Sometimes, private export credit insurers are not willing or able to cover all the risks (especially for large, long-term and risky transactions).

Usual agents of export financing are credit and insurance providing companies. Governments establish public Export Credit Agencies (ECAs) to mitigate financial constraints and risks in exports. Export credit insurance facilitates the export transaction, directly or indirectly, by securing the financing aspect. Not many studies have been prepared about the effectiveness of ECAs in stimulating exports, but recently there is increasing theoretical and empirical evidence that the activities of ECAs have a positive effect on exports (see articles cited by Janssen, 2016). 
Any export strategy is part of the general economic policy of a country, export promoting institutions are part of the general institutional system. Below we focus on state policies announced especially after the crisis. We describe government strategies (if they exist) targeting export development and reforms in main export promoting institutions. We mention, but do not go into details of export financing/credit institutions.

\section{Practice of promotion, similarities, and differences}

In all nine countries of the Baltic, Visegrád and Iberian regions, important government strategies concerning export promotion were announced around 2011-2012 as a reaction to the crisis (see Table 1). 'Made in Estonia 3.0' is Estonia's action plan for the years 2014-2017 for increasing the export capacity of Estonian companies and involving foreign investments (Estonian Ministry of Economic Affairs and Communications, 2014). It is in connection with other strategies and development plans. The action plan sets the following goals: increase Estonia's importance in world trade, increase export turnover across all target countries by at least $10 \%$ per year, increase the number of exporters and growth in average export unit price. The Export Development Strategy 20092013 intended to expand the opportunities of firms to find new trading partners. The next strategy (for 2014-2020; Ministry of Economy of the Republic of Lithuania, 2015) was adopted in 2015 and it establishes export promotion policy and measures. Its priority objectives are (1) to maintain export positions in foreign markets; (2) to penetrate into new markets, especially in third countries; and (3) to promote the export development of higher value-added goods and services.

We have not found separate export promotion strategy of the Latvian government, but the Industrial Development Policy adopted in 2012 (Ministry of Economics of the Republic of Latva, 2012) deals also with export development. For SMEs, the International Promotion of Competitiveness program has been in force since 2008, supporting enterprises entering into foreign markets during and right after the global financial crisis (EC, 2016).

In Slovakia, no separate export strategy had existed either until 2014. However, the Research and Innovation Strategy focused on export trends and development recognising that in Slovakia the production of motor vehicles and consumer electronics are decisive export sectors and aiming to strengthen their position. Later, the Strategy for External Economic Relations of the Slovak Republic 
for 2014-2020 was developed by the Ministry of Foreign Affairs in order to boost exports. The Ministry cooperated with the Slovak Investment and Trade Development Agency (SARIO) and the Slovak Chamber of Commerce and Industry to conduct business forums and missions, visits by state officials to EU and non-EU countries. ${ }^{3}$

The Export Strategy of the Czech Republic 2012-2020 (Ministy of Industry and Trade of the Czech Republic, 2012) aims among others to increase the number of exporters, diversify and shift Czech exports into economic sectors with higher added value, and reduce product concentration (Antalóczy \& Éltetö, 2016).

The export promotion strategy during the crisis was based on four main elements: promotion of brand, economic missions of officials, assistance to Polish firms with information on foreign markets, and financial instruments. In 2016, a most noticeable change is that the support of Polish firms abroad became one of the five pillars of the new general growth strategy (Ministry of Economic Development of Poland, 2016).

The Hungarian export development strategy (called 'Eastern Opening') was adopted in 2011 for the 2012-2015 period. The full text of the strategy was not public, only press information was published about it. The aim was to diversify Hungary's foreign economic relations and developing non-EU relations (towards, for example, CIS countries and China; Government of Hungary, 2011), doubling Hungary's exports and promoting exports of Hungarian SMEs.

The Portuguese government launched a program for internationalisation in 2016 to promote export, attract FDI and support outward investments of Portuguese companies. The Portuguese state promotion for internationalisation is heavily supported by the EU funds. The biggest Operational Programme in Portugal is Competitiveness and Internationalization, which is co-funded with 4.4 billion euros through both Structural Funds, as well as through Cohesion Fund. This means $21 \%$ of the available funds for Portugal (EC, 2014).

The Strategic Plan of Internationalisation of the Spanish Economy was approved by the government in February 2014 (Ministerio de Economía y Competitividad, 2014-2015). This is a 120-page document outlining the weaknesses and strengths of Spanish external sector and setting development aims, measures and tools. The plan is based on six axles: (1) improving negotiating and business

3 In 2013, aiming to increase exports from SMEs, SARIO together with other institutions launched a project called Misia 14 - Made in Slovakia. Firms were encouraged to express their opinions on problems with exports via an online questionnaire. (The Slovak Spectator, 2013) The results, however, are not known. 
climate for firms; (2) improve market access; (3) financial support facilities; (4) trade and internationalisation promotion; (5) human capital development; and (6) innovation promotion. The Strategic Plan describes 41 definite measures, dedicated sums and institutions along the axles to support the defined aims and priorities.

\section{Table 1. State export policies and institutions in the observed countries}

\begin{tabular}{|c|c|c|c|c|c|c|}
\hline & $\begin{array}{l}\text { Government strategy } \\
\text { for export or inter- } \\
\text { nationalisation }\end{array}$ & $\begin{array}{c}\text { 'Soft' } \\
\text { tools, } \\
\text { agencies }\end{array}$ & $\begin{array}{l}\text { 'Direct' } \\
\text { tools, } \\
\text { financing } \\
\text { (export } \\
\text { credit } \\
\text { agency) }\end{array}$ & $\begin{array}{l}\text { Re- } \\
\text { gional } \\
\text { promo- } \\
\text { tion }\end{array}$ & $\begin{array}{l}\text { Need for } \\
\text { diversi- } \\
\text { fication }\end{array}$ & $\begin{array}{l}\text { Importance } \\
\text { of innova- } \\
\text { tion, higher } \\
\text { value-added } \\
\text { connected to } \\
\text { export }\end{array}$ \\
\hline Estonia & $\begin{array}{l}\text { EAS Strategy } \\
\text { 2015-2018 }\end{array}$ & EAS & KredEx & weak & geographical & yes \\
\hline Latvia & $\begin{array}{l}\text { No separate strategy } \\
\text { Part of Industrial } \\
\text { Development Policy }\end{array}$ & LIAA & ALTUM & no & geographical & yes \\
\hline Lithuania & $\begin{array}{l}\text { Export Development } \\
2014-2020\end{array}$ & $\begin{array}{l}\text { Enter- } \\
\text { prise } \\
\text { Lithuania }\end{array}$ & INVEGA & weak & geographical & yes \\
\hline Poland & $\begin{array}{l}\text { New Development } \\
\text { Strategy } 2016\end{array}$ & $\begin{array}{l}\text { PalilZ/ } \\
\text { PAHil }\end{array}$ & KUKE & strong & geographical & yes \\
\hline $\begin{array}{l}\text { Czech } \\
\text { Republic }\end{array}$ & $\begin{array}{l}\text { Export Strategy } \\
2012-2020\end{array}$ & $\begin{array}{l}\text { Czech- } \\
\text { Trade }\end{array}$ & CEB, EGAP & weak & $\begin{array}{l}\text { geographical } \\
\text { and product }\end{array}$ & yes \\
\hline Slovakia & $\begin{array}{l}\text { Part of Research and } \\
\text { Innovation and National } \\
\text { Development Strategy. } \\
\text { Later, the Strategy for } \\
\text { External Economic } \\
\text { Relations of the Slovak } \\
\text { Republic for 2014-2020 }\end{array}$ & SARIO & Eximbanka & no & geographical & yes \\
\hline Hungary & "Eastern Opening" & $\begin{array}{l}\text { HIPA, } \\
\text { trade } \\
\text { houses }\end{array}$ & Exim & no & geographical & no \\
\hline Portugal & $\begin{array}{l}\text { Program for Internation- } \\
\text { alisation }\end{array}$ & AICEP & COSEC & weak & geographical & yes \\
\hline Spain & $\begin{array}{l}\text { Strategic Plan of Inter- } \\
\text { nationalisation of the } \\
\text { Spanish Economy }\end{array}$ & ICEX & $\begin{array}{l}\text { CESCE, } \\
\text { ICO }\end{array}$ & strong & $\begin{array}{l}\text { geographical } \\
\text { and product }\end{array}$ & yes \\
\hline
\end{tabular}


A common feature of post-crisis policies is that the importance of non-EU markets emerges in every country. In Estonia, the export target countries are the neighbouring economies (Latvia, Lithuania, Finland and Russia), countries of the Hanseatic Road (Sweden, Norway, Denmark, Germany, Great Britain, France, the Netherlands and Belgium) and faraway markets (the large countries in Asia, USA and Brazil). In Lithuania, also three priority export market groups were identified by the government: enlargement markets-Sweden, Norway, Germany, the United Kingdom, France; perspective markets-USA, China, Israel, Japan, Ukraine; and exploratory markets - the UAE, Canada, Turkey and the Republic of South Africa. In the Polish development plan there is a focus on some new Asian, African and American markets. New trade posts are to be created in these countries. In the Czech strategy, 12 priority countries were defined: Brazil, People's Republic of China, India, Iraq, Kazakhstan, Mexico, Russian Federation, Serbia, Turkey, Ukraine, USA and Vietnam. Another target group covers the so-called "countries of interest", with 25 developing markets ${ }^{4}$. The Hungarian foreign economic strategy—even named Eastern Opening Strategy - puts emphasis on developing trade relations with China, India, Russia, South Korea, Turkey, ASEAN member states, Arab countries and CIS. In Slovakia, the aim is to increase exports to the EU, the Balkans, CIS, certain countries of the EU's Southern Neighbourhood, and Africa and Asia (Ministry of Foreign and European Affairs of the Slovak Republic, 2014). In the Iberian economic strategies, the importance of non-EU emerging markets was also emphasised.

Among the non-EU emerging markets, China is one of the most of important target markets in all the nine countries. After the crisis, economic policy in the Visegrád countries intended to strengthen trade and investment ties with China. Traditionally, Hungary has had the strongest links and the largest Chinese diaspora in CEE, but recently Poland and the Czech Republic also intensified diplomatic missions and common economic projects (Éltető-Szunomár, 2016). ${ }^{5}$

4 Angola, Argentina, Australia, Azerbaijan, Belarus, Egypt, Ethiopia, Chile, Ghana, Croatia, Israel, Japan, South Africa, Canada, Columbia, Morocco, Moldavia, Nigeria, Norway, Peru, Senegal, Singapore, United Arab Emirates, Switzerland and Thailand

5 The Central-Eastern European region also became important for China itself. In 2012, during his visit at the First CEE-China Summit in Poland, the Chinese Prime Minister officially launched a cooperation plan with 16 CEE countries called the Warsaw initiative. The following summits have taken place in Bucharest, Romania (2013); Belgrade, Serbia (2014); Suzhou, China (2015) and Riga, Latvia (2016). Active measures have been taken in investment, trade, infrastructure development to strengthen the ties with the CEE region. 
Concerning the export promoting institutions in our three regions, many of them have been reorganised, centralised after the crisis. In Poland and Hungary, this step was radical and followed a previous government change. Regarding institutional system in Poland, the Ministry of Economic Development was created through the merger of Ministry of Infrastructure and Regional Development and, partly, a Ministry of Economy. Instead of the previous dispersed institutions and agencies controlled by different ministries, one greater umbrella-type agencyThe Polish Development Fund - was founded. It is controlled by the Ministry of Economic Development. This fund coordinates many other agencies such as the Polish Agency of Enterprise Development, Export Credit Insurance Corporation Joint Stock Company (KUKE), the Polish Agency of Trade and Investment (PAHiI). The budget of this Agency will be almost ten times more (100 million zlots) in 2017 than in 2016 (12 million zlots). (Ministerstwo Rozwoju, 2016)

In Hungary, those export promoting and financing institutions that had existed for decades were reformed and centralised. Their direction and ownership was transferred to the Ministry of Economy. Investment promotion is the task of Hungarian Investment Promotion Agency (HIPA, n.d.) and export promotion is the task only of the National Trading House (NTH), established in 2013. NTH has opened trade houses in more than 40 economies, ${ }^{6}$ its functioning, however, is not transparent and produces yearly loss. The agency for export financing is EXIM, a merge of the Hungarian Export-Import Bank Plc. (Eximbank) and the Hungarian Export Credit Insurance Plc. (MEHIB).

In Slovakia, the National Business Centre (launched in 2015) serves as an umbrella organisation providing different forms of institutional support to all entrepreneurs interested in expanding their business abroad. It is financed through the operational programme for Research and Innovation and operates via the Slovak Business Agency under the Ministry of Economy.

In the Iberian economies, export promoting institutions were also reorganised to some extent. The main export promoting agency in Portugal is AICEP (n.d.), Portugal Global Trade \& Investment Agency created in 2007 (with a merger of API and Icep, former investment and economic promotion agencies), for attracting investors in Portugal and contributing to the success of Portuguese companies abroad in their internationalization processes or export activities. The agency has a global network, provides support services, counselling, tailored information. AICEP Portugal Global Group also includes AICEP Global Parques - an industrial parks management entity. As far as export

6 There are a number of faraway countries among them (Botswana, Namibia, Laos, South Africa, Mexico, Peru, Ecuador, Cambodia, Indonesia, Armenia, Kazahstan, etc.). 
credit is concerned, the private insurance firm COSEC has the mandate to manage the official export credit guarantee scheme on behalf of the Portuguese government. The government established a Strategic Council for Economic Internationalisation (Conselho Estratégico de Internacionalização da Economia, or CEIE) already in 2012 to integrate public and private initiatives.

The main state agency for Spanish export promotion is ICEX. ${ }^{7}$ It has an extensive internet homepage (ICEX, n.d.) and a large network of offices both within Spanish regions and abroad. ICEX launched at its homepage the socalled Ventana Global ('Global window'), which offers all public services and information ${ }^{8}$ in integrated form with direct access for exporting and investing companies. In 2012, ICEX was reorganised, it integrated Invest in Spain, and later it incorporated also CECO (Commercial and Economic Study Centre) and the state society España, Expansión Exterior. This way ICEX became the only anchor for internationalising Spanish firms.

In the Baltic countries, institutional reorganisation occurred only on minor scale. In Estonia, the most important promotion agency is Enterprise Estonia (EAS), founded in 2000. Regarding Export, the credit institution KredEx was founded in 2009. In Latvia, the main institution of export and investment promotion is LIAA (Latvian Investment and Development Agency) which belongs to the Ministry of Economy. Regarding export finance, ALTUM (Development Finance Institution) provides export credit guarantees and insurance. It was started in 2015 as the successor of the Latvian Guarantee Agency, founded in 1998. It is a state joint stock company and administers financial state aid targeting mainly SMEs, start-ups. In Lithuania, the agency Enterprise Lithuania has the task to foster the country's exports. The export guarantee institution (INVEGA) was established in 2001 for SME development and is supervised by the Ministry of Economy.

As government documents show, in all our nine countries (except for Hungary) the governments realised the importance of a coherent economic policy and connected export promotion policy with other development strategies. Innovation, research and development and increasing domestic value added serve as a basis for medium and long-term export development.

7 It was established in 1982 and had the present abbreviation since 1987, meaning Instituto Espańol de Comercio Exterior. Since 2012 together with organisational changes its official name changed to ICEX Espana Exportaciónes e Inversiones.

8 Secretaría de Estado de Comercio del Ministerio de Economía y Competitividad, ICEX Compañia Española de Financiación del Desarrollo (COFIDES), Compañía Española de Seguro de Crédito a la Exportación (CESCE), Sociedad Estatal España Expansión Exterior, Instituto de Crédito Oficial (ICO), Enisa, Centro para el Desarrollo Tecnológico Industrial (CDTI). 
Certainly we can find important differences among the policies. Government strategies are in some cases very detailed, well prepared and coordinated with other policies (e.g., in Spain, Czech Republic, Estonia) and there are countries where export strategy is only a part of other policies or it is not completely public (in Latvia, Slovakia, Hungary). The level of transparency of state actions is also different. The least transparent is the Hungarian system of trade-houses, but in the case of Portuguese and Spanish export financing agencies concerns have been raised too. ${ }^{9}$

Although the geographical diversification of exports appears everywhere as a policy goal, the aim of product structure diversification can be find only in the Czech and Spanish strategies.

In Spain and Poland - as large countries where the level of decentralization is higher than in small economies - the role of regional export promotion is also important. (Spanish regional governments have established a network of regional export promotion offices abroad ${ }^{10}$ ). In certain countries, the strengthening of the country brand, country-image came also into focus (marca Portugal, marca España, marka Polska) and became integrated into the export promotion system, while in other cases this was not in focus. Some government strategies (Spain, Poland, Estonia, Latvia) recognised that export promotion is connected to industrial policy and human capital development.

\section{Trends in trade}

As we have seen above, non-EU export was explicitly promoted by the states. Therefore, in 2010-2011, extra-EU exports increased very dynamically in our observed countries (see Figs. A1-A3 in Annex). However, later on a stagnation or decline of extra-EU exports has been experienced. Although this recent trend is similar across countries, the reasons can be somewhat different.

9 Portugal: "since May 2010 until January 2014, COSEC did not disclose on its website any information on the projects supported. [...] The quality and the quantity of the information disclosed by COSEC do not allow civil society to efficiently monitor its activity." In Spain, CESCE was given legal protection in maintaining strictest confidentiality about data held on the projects they insure (see http://www.eca-watch. org/ecas).

10 Since the mid-nineties there has been a proliferation of these regional offices all over the world. Gil-Pareja et al. (2015) found that the activity of these offices had significant effects on aggregate exports. 
In the case of the Baltic countries, the main reason for the sharp decline of extraEU deliveries is that the share of Russia in the total export fell (from around $20 \%$ in 2014 to $6-13 \%$ in 2015). ${ }^{11}$ In the case of the Visegrád countries, extraEU export increased until around 2012, but later stagnated and slightly declined. There was a significant export volume decrease to Russia, Ukraine, some CIS and African states. At the same time, export towards the EU increased dynamically.

Spanish and Portuguese exports to non-EU areas show a stagnation since 2013, but export to the EU (and total export) increased here also. Among the non-EU areas exports recently decreased to Venezuela, Ecuador, Russia, China, Brazil. Until 2015, Portugal's exports decreased also to Angola, which otherwise had become a promising export market in the last decade. Spanish exports have grown at a much faster pace than GDP since 2010. Spanish companies have become more and more internationalised ${ }^{12}$, their presence in China, Latin America and Africa have increased.

Table 2 shows some export markets for our nine countries. All but one among the most important targets are EU members; the exception is Russia which is very significant for Baltic export. For the Iberian economies, France, Germany, Italy and UK are the most important export markets and for Portugal, the neighbouring Spain is by far the most relevant. In the case of the Visegrád countries the export dependency on Germany is apparent. Of exports, 25-30\% are directed to Germany from each country (and these are only the direct deliveries, indirect exports via each other for example elevate this dependency even more). For the sake of comparison, the share of China (PRC) is also given in total manufacturing exports. The table shows that in those countries where the activity of foreign multinational companies is significant, the weight of China is larger in the exports. ${ }^{13}$

11 From 2014, the Russian countersanctions against the EU sanctions involved an embargo on several agricultural and food products, including meat, dairy products, fruit, and vegetables. The export of the Baltic and Visegrád states have been significantly affected by the countersanctions. Apart from the countersanctions, other developments of the common agricultural policy in the EU, the depreciation of the rouble, the economic slowdown in Russia also had an effect on exports to Russia.

12 There were 99,000 exporting firms in 2009 and 147,000 firms in 2015 (García-Legaz, 2016).

13 As Eurostat data for 2015 show, in Portugal and Slovakia there is a huge product concentration, $40 \%$ and $64 \%$ of exports to China consists of motor vehicles, in Hungary $14 \%$ of exports to China consists of piston engines (all deliveries of the local Volkswagen group plants). The largest Polish exports item to China (33\%) is copper and copper ores are also significant in the export of Portugal (12\%) and Spain (4.8\%). Copper is the base material of electric circuits and other products made in China. 
Table 2. Main export partners and the export-weight of China in the observed countries, 2015 (\% of total exports of goods)

\begin{tabular}{|c|c|c|c|c|c|c|c|}
\hline \multicolumn{2}{|c|}{ Latvia } & \multicolumn{2}{|c|}{ Estonia } & \multicolumn{2}{|c|}{ Lithuania } & & \\
\hline LIT & 17.75 & SWE & 18.81 & RUS & 13.66 & & \\
\hline RUS & 11.44 & FIN & 16.00 & LAT & 9.83 & & \\
\hline EST & 11.05 & LAT & 10.35 & POL & 9.72 & & \\
\hline GER & 6.24 & RUS & 6.65 & GER & 7.80 & & \\
\hline POL & 5.54 & LIT & 5.85 & EST & 5.33 & & \\
\hline PRC & 0.99 & PRC & 1.17 & PRC & 0.45 & & \\
\hline \multicolumn{2}{|c|}{ Czech Rep. } & \multicolumn{2}{|c|}{ Slovak Rep. } & \multicolumn{2}{|c|}{ Hungary } & \multicolumn{2}{|c|}{ Poland } \\
\hline GER & 32.41 & GER & 22.65 & GER & 28.03 & GER & 27.14 \\
\hline SK & 8.97 & $\mathrm{CZ}$ & 12.49 & ROM & 5.42 & UK & 6.76 \\
\hline POL & 5.84 & POL & 8.52 & SK & 5.12 & $\mathrm{CZ}$ & 6.60 \\
\hline UK & 5.27 & AUS & 5.68 & AUS & 4.98 & FRA & 5.54 \\
\hline FRA & 5.10 & $\mathrm{HU}$ & 5.68 & IT & 4.76 & IT & 4.77 \\
\hline PRC & 1.16 & PRC & 1.50 & PRC & 1.42 & PRC & 1.02 \\
\hline \multicolumn{2}{|c|}{ Spain } & \multicolumn{2}{|c|}{ Portugal } & & & & \\
\hline FRA & 15.57 & SP & 24.98 & & & & \\
\hline GER & 10.89 & FRA & 12.13 & & & & \\
\hline UK & 7.33 & GER & 11.82 & & & & \\
\hline IT & 7.32 & UK & 6.72 & & & & \\
\hline POR & 7.06 & US & 5.15 & & & & \\
\hline PRC & 1.74 & PRC & 1.68 & & & & \\
\hline
\end{tabular}

Source: Eurostat Comext database

Everywhere among the most important five export partners we can find neighbouring countries. This shows the reinforced importance of intra-regional trade. Regarding shares in foreign trade, the Baltic countries have the strongest strengthening ties with each other. Here we should mention re-exporting as an important part of trade in the Baltic countries (Lietuvos Bankas, 2014; Benkovskis et al., 2016; Kerner 2012). The main reason for that is that given the small size of the countries, logistics chains treat the Baltics as one region. In 
Baltic ports, firms often operate warehouses serving more than one of the Baltic States. A main direction of re-export is the Russian market and an important exports item are petroleum oil products. ${ }^{14}$

Regarding the intra-regional trade of the Visegrád countries, here the activities of global production networks or value chains (GVCs) is the most important drive. The Visegrád countries export large volumes of automotive, telecommunication, electrical and metal products to each other within the intra-firm trade of multinational companies. As is known, Hungary, the Czech Republic and Slovakia are especially strongly linked to global value chains (see Éltetö, 2015 and the studies cited there). Inclusion into GVCs is usually measured by the foreign value added content of exports based on world level input-output tables. Naturally, as foreign value added in exports increases, the domestic value added decreases. Antalóczy and Éltetö (2016) calculated the share of domestic value added for the period of 1995-2011 for the nine countries. The most radical decrease (from $66 \%$ to $48 \%$ ) can be observed for the Visegrád economies and the bulk of this decrease took place before 2005 as a consequence of economic liberalisation and FDI inflow during the nineties.

The importance of intra-trade within the Iberian countries is asymmetrical for the two countries. Portugal is much more dependent on Spain than vice versa, and the trade balance is increasingly favourable for Spain. Three factors are important in intra-Iberian trade: natural geography, re-export and global production chains. Bordering regions in the two neighbouring countries have an important role in mutual trade. Galicia has the highest trade volume with Portugal, followed by Andalusia, Castile and León, and Extremadura (Pérez Castro et al., 2015). Similarly to the Baltic countries, the ports in Portugal play an important role in re-export. In the largest, deep sea port of Sines there is a big oil refinery of Galp Energia built in 1971 and it has become a major energy hub. ${ }^{15}$ Portugal does not have own crude oil, it is dependent on imported oil. Despite this, petroleum products are the leading export items of Portugal to the EU (mainly Spain), indicating re-export activity. Intra-Iberian trade has been also boosted by the growing local activity of global value chains. Amador and Stehrer (2014) analysed

14 Petroleum oil products are leading export items in other cases too. In Estonia, Russian oil is exported to other countries through Estonia's ports. In Lithuania, refining oil is also important-PKN Orlen Lietuva is the most significant supplier of petrol and diesel fuel in the Baltic countries, its products are also exported to Western Europe, USA, Ukraine, and other countries.

15 Sines has a good chance to attract traffic to and from Madrid, from vessels not calling at Mediterranean ports or for shippers targeting to trade directly with South American and African markets. Sines port also hosts the only LNG terminal of Portugal. 
Portuguese integration into GVCs between 1995 and 2011, demonstrating the strengthening of Iberian GVCs.

Based on the data we can confirm that significant geographical diversification of exports has not taken place, despite government intentions. Diversification of product structure has not taken place either, as the concentration indices calculated by Antalóczy and Éltető (2016) prove; in fact, in several cases exports have become less diversified after the crisis.

\section{Conclusion}

After experiencing the negative effects of the international crisis in 2008-2009, each country recognised the importance of export as a motor of growth. The Baltic, Iberian and Visegrád economies have become much more exportdependent. Export promotion became a state policy aim with an own strategy in most cases. In these documents the strengthening of export to non-EU areas is generally an important goal, emerging target markets, such as China are named. However, trade data show that the share of EU in exports decreased only temporarily and slightly, after which it regained its previous position.

The slowing down of the emerging markets is, of course, one external factor behind this phenomenon. Our paper, however, examined the internal reasons of this "return to the EU". We showed the importance of intra-regional trade, partly based on re-export. Foreign trade of the examined periphery countries is still structured around the neighbours (Russia, Sweden for the Baltic countries, France, UK, Italy for the Iberian countries, and Germany as almost a unique hub for the Visegrád countries).

Most exporting firms in these economies are part of global value chains. These GVCs are directed by foreign multinationals, the activity of which cannot be really influenced by local governments. ${ }^{16}$ Good state policies recognise this and try to create a favourable economic environment and incentives for domestic firms to gain adequate positions within GVCs. In the Slovakian case, for example, the strong export dependence on cars and components was accepted by the state, and more domestic value-added production was promoted within the automotive production chains. Most government development strategies aim small and medium sized firms, sometimes explicitly targeting national companies.

16 This trade-determining role of GVCs is the most apparent in the trade with China. 
Although product diversification was also a policy aim in certain countries, concentration has not changed significantly. This shows that export diversification is a long-term process and concentration also largely depends on the massive deliveries of suppliers into GVCs.

Studies and surveys show that the evaluation of state promotion policies is mixed. Information services and cost financing are the most important for exporting companies. According to our opinion, an export strategy can only be effective if it is part of a coherent economic policy, it is transparent and provides a stable environment for the firms. The development of human capital is also essential in this respect.

Andrea Éltető, $\mathrm{PhD}$ is senior research fellow, director of the Research Group on European Integration at the Institute of World Economics, CERS, Hungarian Academy of Sciences. Her major fields of research are foreign direct investment, foreign trade and economic development of Spain and Portugal in the European Union. She finished her graduate and postgraduate studies at the Budapest University of Economic Sciences and participated in several international research projects. She is a member of the European Association of Comparative Economic Studies, a scientific committee of the Hungarian Academy of Sciences and external research fellow at the Instituto de Economia Internacional, Universitat Jaume I, Valencia.

Katalin Antalóczy, PhD is professor at the Faculty of International Management and Business in Budapest Business School, and senior research fellow at the Financial Research Ltd. Budapest. She obtained her PhD from the Hungarian Academy of Science in 1994. Her research focused on globalisation, foreign direct investment, foreign trade and pharmaceutical industry. She has participated in various Hungarian and international research projects. Antalóczy has published more than 100 books, book chapters, academic research articles including 'Through a Glass Darkly. The Content of Statistical Data on Foreign Direct Investment,' Studies in International Economics, vol. 1, no. 1, August 2015 (with Magdolna Sass) and 'Hungary in the Global Value Chains-the Foreign Trade Network,' Prosperitas, no. 1, 2017. 


\section{References}

AICEP (n.d.), Associação para o Investimento e Comércio Externo de Portugal. Retrieved from http://www.portugalglobal.pt/EN/about-us/Pages/about-us. aspx\#sthash.0U245B6L.dpuf [accessed May 2017]

Amador, J. \& Stehrer, R. (2014), 'Portuguese exports in the global value chains,' Banco de Portugal Economic Bulletin, April, pp. 64-78.

Antalóczy, K. \& Éltetö, A. (2016), Post-crisis foreign trade trends and policies on the periphery of the European Union - comparison of the Iberian, Baltic and Central European region, IWE Working Paper, no. 224.

Bacchetta, M.; Jansen, M.; Lennon, C. \& Piermartini, R. (2009), 'Exposure to external shocks and the geographical diversification of exports,' in R. Newframer et al. (eds.) Breaking into New Markets. Emerging Lessons for Export Diversification, Chapter 4, Geneva: The World Bank.

Benkovskis, K.; Bērziņa, S. \& Zorgenfreija, L. (2016), "Evaluation of Latvia's reexports using firm-level trade data," Baltic Journal of Economics, vol. 16, no. 1, pp. 1-20. https://doi.org/10.1080/1406099X.2016.1163891

Durmuşoğlu, S.; Apfelthalter, G.; Nayir, D. Z.; Alvarez, R. \& Mughan, T. (2012), 'The effect of government-designed export promotion service use on small and medium-sized enterprise goal achievement: A multidimensional view of export performance,' Industrial Marketing Management, no. 41, pp. 680-691.

https://doi.org/10.1016/j.indmarman.2011.09.016

EC (2014), Competitiveness and Internationalisation OP: Portugal, EU Regional Policy programme. Retrieved from http://ec.europa.eu/regional_policy/en/atlas/ programmes/2014-2020/portugal/2014pt16m3op001 [accessed May 2017] (2016), 2016 SBA Fact Sheet - Latvia, European Commission Directorate-General for Internal Market, Industry, Entrepreneurship and SMEs. Retrieved from http://ec.europa.eu/DocsRoom/documents/22382/attachments/20/translations/en/ renditions/native [accessed May 2017]

Éltető, A. (2015), 'Foreign trade tends in the EU10 countries,' in A. Éltető (ed.) Mind the Gap. Integration Experiences of the Ten Central and Eastern European Countries, Budapest: Centre for Economic and Regional Studies of the Hungarian Academy of Sciences, Institute of World Economics, pp. 41-60.

Éltető, A. \& Szunomár, Á. (2016) 'Chinese investment and trade - strengthening ties with Central and Eastern Europe,' International Journal of Business and Management, vol. 4, no. 1, pp. 24-48.

Estonian Ministry of Economic Affairs and Communications (2014), Made in Estonia 3.0, The Estonian foreign investments and export action plan for the years 20142017 for increasing the export capacity of Estonian companies and involving 
foreign investments. Retrieved from https:/www.mkm.ee/sites/default/files/ mie_3.0_english_version.pdf [accessed May 2017]

García-Legaz, P. J. (2016), 'Logros y retos del sector exterior de la economía espanola,' in Economistas, no. 148, Madrid: Colegio de Economistas, pp. 6-9.

Gil-Pareja, S.; Llorca-Vivero, R.; Martinez-Serrano, J. A. \& Requena-Silvente, F. (2015), 'Regional export promotion offices and trade margins,' Review of World Economy, vol. 151, pp. 145-167. https://doi.org/10.1007/s10290-014-0199-0

Government of Hungary (2011), Külgazdasági Stratégia. Retrieved from http://www. kormany.hu/download/1/d7/30000/kulgazdasagi_strategia.pdf [accessed May 2017]

Head, K. \& Ries, J. (2010), 'Do trade missions increase trade?' Canadian Journal of Economics, vol. 43, no. 3, pp. 754-775.

HIPA (n.d.), Hungarian Investment Promotion Agency. [Homepage] Retrieved from www.hipa.hu/main [accessed May 2017]

ICEX (n.d.), ICEX España Exportación e Inversiones. [Homepage] Retrieved from www.icex.es [accessed May 2017]

Janssen, C. (2016), Design of Export Credit Agencies, MA thesis, Erasmus University of Rotterdam.

Kerner, R. (2012), "Estonia's trade in the world of globalisation," Quarterly Bulletin of Statistics Estonia, no. 2.

Kotabe, M. \& Czinkota, M. R. (1992), 'State government promotion of manufacturing exports: a gap analysis,' Journal of International Business Studies, vol. 23, no. 4, pp. 637-658. https://doi.org/10.1057/palgrave.jibs.8490281

Lietuvos Bankas (2014), Economic Review, May 2014, Vilnius.

Los, B.; Timmer, M. \& de Vries, G. (2015), "Global value chains: 'Factory World' is emerging," in J. J. Amador \& F. di Mauro (eds.) The Age of Global Value Chains: Maps and Policy Issues, London: CEPR Press, pp. 36-47.

Malaket, A. R. (2014), Financing Trade and International Supply Chains: Commerce Across Borders, Finance Across Frontiers, Surrey \& Burlington: Gower.

Ministerstwo Rozwoju (2016), Program wspierania ekspansji międzynarodowej polskich przedsiębiorstw. Retrieved from https://www.mr.gov.pl/strony/aktualnosci/ program-wspierania-ekspansji-miedzynarodowej-polskich-przedsiebiorstw/ [accessed May 2017]

Ministry of Economic Development of Poland (2016), Plan na Rzecz Odpowiedzialnego Rozwoju, Draft of document disseminated to public consultations, 29 July 2016. Retrieved from https:/www.mr.gov.pl/media/23749/SOR_29072016_projekt.pdf [accessed May 2017]

Ministry of Economics of the Republic of Latvia (2012), Guidelines on National Industrial Policy of Latvia (Unofficial translation). Retrieved from https://www. em.gov.lv/files/uznemejdarbiba/finl_en.pdf [accessed May 2017] 
Ministry of Economy of the Republic of Lithuania (2015), 'Export promotion policy.' Retrieved from https://ukmin.lrv.lt/en/sector-activities/export/export-promotionpolicy [accessed May 2017]

Ministry of Foreign and European Affairs of the Slovak Republic (2014), Assessment of Foreign and European Policy Tasks of the Slovak Republic. Retrieved from https:/www.mzv.sk/documents/30297/124956/150420_sprava_ZP_EN_.pdf [accessed May 2017]

Ministry of the Industry and Trade of the Czech Republic (2012), Export Strategy of the Czech Republic. Retrieved from http://www.mpo.cz/dokument104211.html [accessed May 2017]

Moons, S. J. V. \& Van Bergeijk, P. A. G. (2013), Economic Diplomacy Works: A meta-analysis of its effect on international economic flows, Prepared for MAER Colloquium.

Nitsch, V. (2005), State Visits and International Trade, CESifo Working Paper, no. 1582.

Pérez Castro, M. Á.; Montero Alonso, M. Á. \& Santos Amaro, A. C. (2015) 'The impact of the euro in the balance of trade (BOT): the Iberian case, Spain-Portugal,' Coimbra Business Review, vol. 1, no. 1, December.

Rose, A. K. (2007), 'The foreign service and foreign trade: embassies as export promotion,' World Economy, vol. 30, no. 1, pp. 22-38. https://doi.org/10.1111/ j.1467-9701.2007.00870.x

Singer, T. O. \& Czinkota, M. R. (1994), 'Factors associated with effective use of export assistance,' Journal of International Marketing, vol. 2, no. 1, pp. 53-71.

The Slovak Spectator (2013), 'Misia 14 wants SMEs to export more.' Retrieved from http://spectator.sme.sk/c/20048356/misia-14-wants-smes-to-export-more.html [accessed May 2017]

Van Biesebroeck, J.; Konings, J. \& Volpe Martincus, C. (2015), 'Did export promotion help firms weather the crisis?' Paper prepared for the 62nd Panel Meeting of Economic Policy, 16-17 October 2015. 


\section{ANNEX}

Figure A1. Export to EU and non-EU areas, Baltic countries
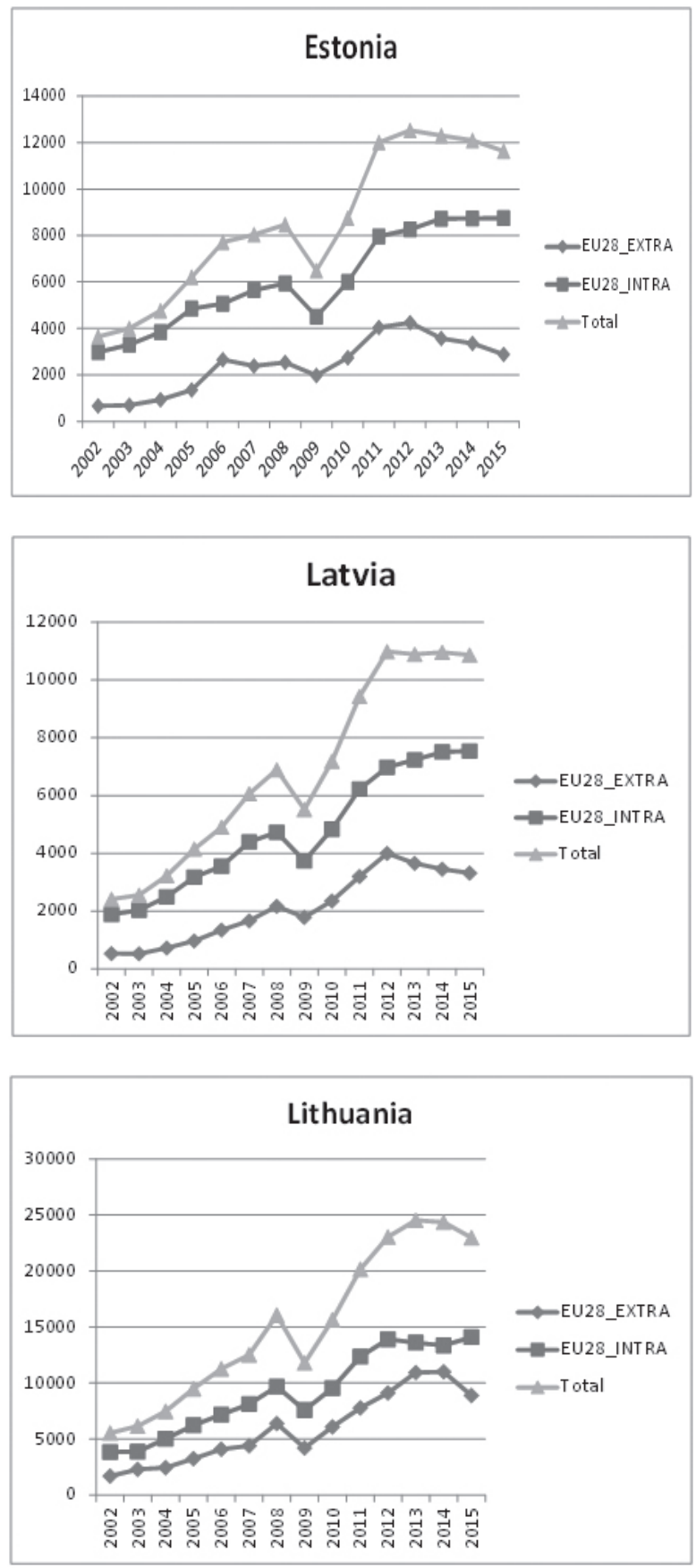
Andrea Élteto"

Katalin Antalóczy

Figure A2. Export to EU and non-EU areas, Visegrád countries
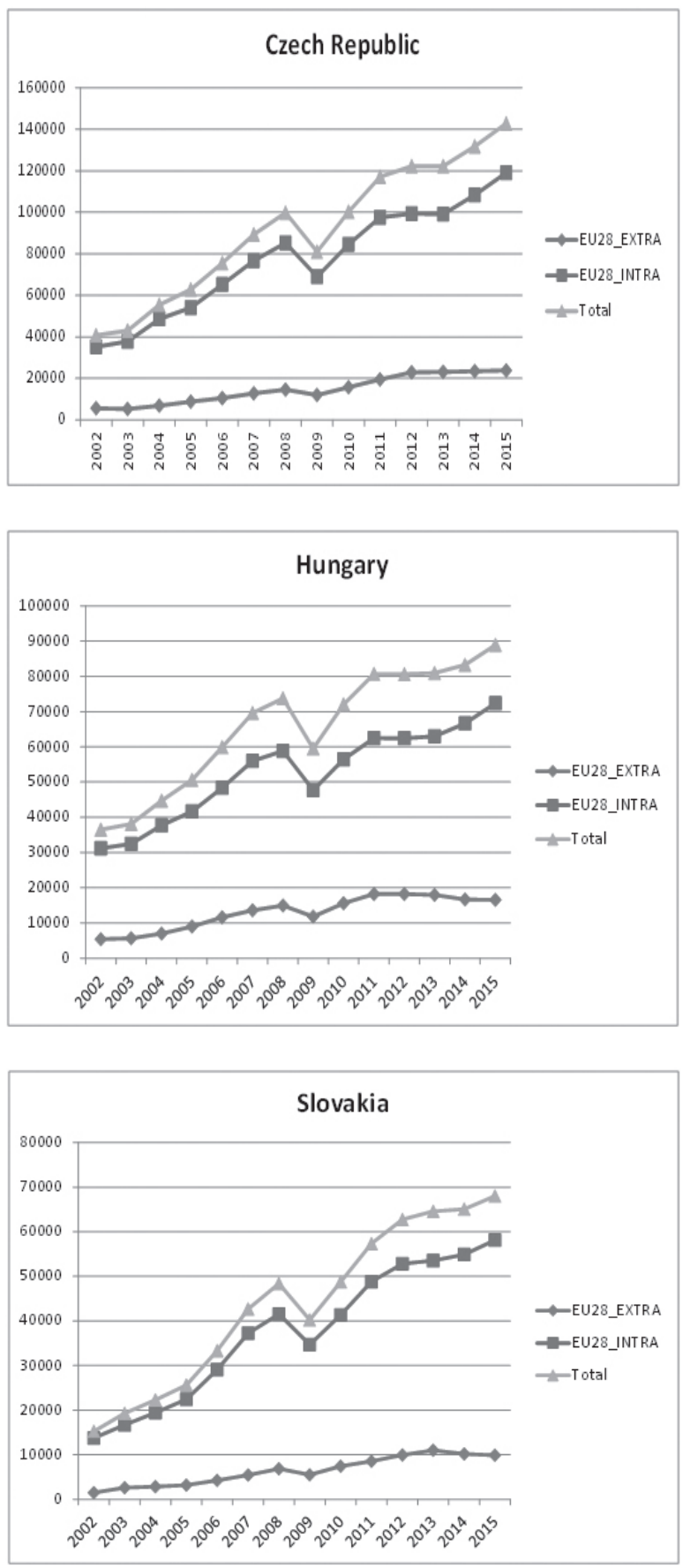

62

Baltic Journal of European Studies

Tallinn University of Technology (ISSN 2228-0588), Vol. 7, No. 1 (22) 
Figure A3. Export to EU and non-EU areas, Iberian countries
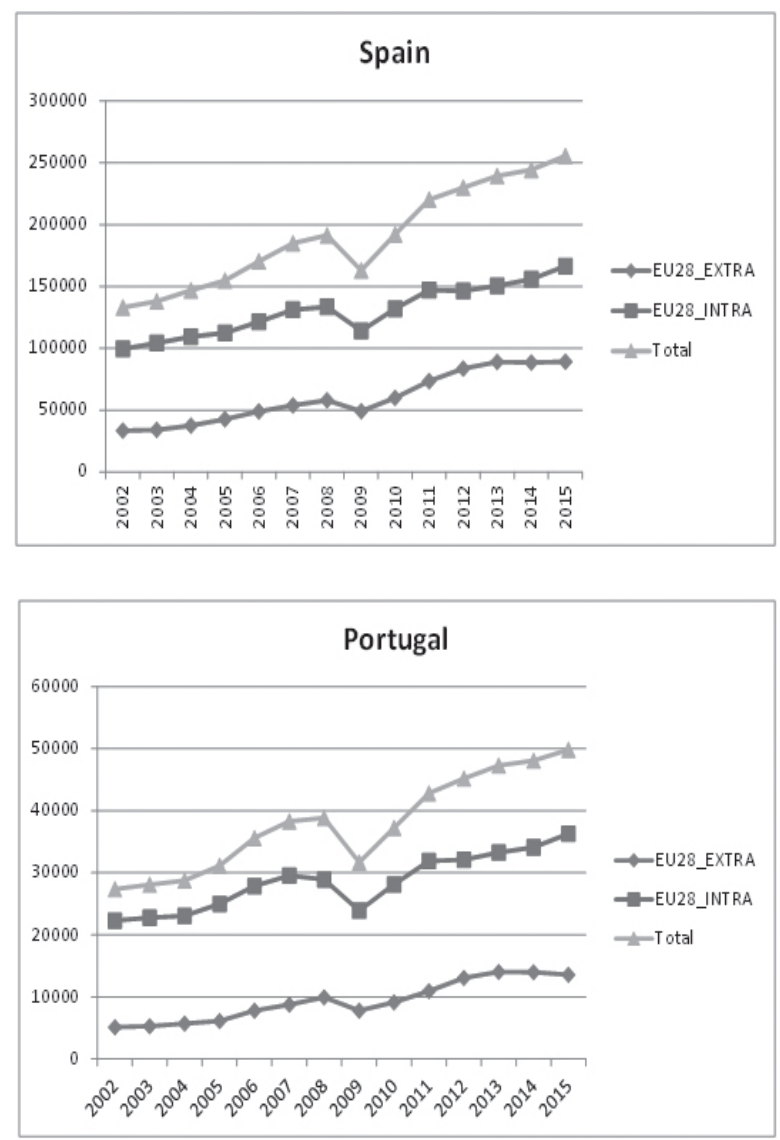

Source: Eurostat Comext 